\title{
A Comparative Study on Rendering of Expressive Meaning in the Main Register of "Jinling Prophecies" and the Twelve Songs in Hong Lou Meng
}

\author{
Wensi Xue \\ School of Foreign Languages, Shaanxi Normal University, China
}

\begin{abstract}
"Jinling Prophecies" and the twelve songs in Hong Lou Meng are considered to be a dominating outline that echoes the former plots and starts the latter, and most importantly, hint the tragic fates of the twelve female characters. Grounded in the classification of lexical meaning by D. A. Cruse, the author of the paper uses textual analysis on lexical selection which Cao Xueqin had made in "Jinling Prophecies" and the twelve songs and has a comparative study on rendering of expressive meaning in two English versions from perspectives of culture, language, and psychology, examining to what extent the expressive meaning can be rendered and how much they have been rendered, in order to find proper criteria for rendering of expressive meaning in poetry translation. Moreover, here would be the first time the concealing psycho-information of Cao Xueqin and the main characters are analyzed as a research object on expressive meaning in translation studies, hoping to contribute a little to the translation practice.
\end{abstract}

Key Words: Hong Lou Meng, "Jinling Prophecies" twelve songs, rendering of expressive meaning, criteria for rendering of expressive meaning

\section{Introduction}

Hong Lou Meng (A Dream of Red Mansions/ The Story of the Stone), one of the greatest Chinese Classical novels, has been translated into dozens of languages since 1830s either in abridged versions or complete ones. In chapter 5, "Jinling Prophecies" can be seen as the key to interpreting the whole novel for dropping hints on final fate of the main female characters. The twelve songs, also in this chapter, are considered to be the epitome of Hong Lou Meng. Thus "Jinling Prophecies" and the twelve songs as a whole not only contains a large amount of information but also presents the unique artistic ways of Chinese classical poetry, in which the expressive meaning rendered by Cao Xueqin is concealed. Only in a way recognized by target readers, can the information and implications in the original text transmitted and felt trough the translations. Based on previous studies, this paper is to have a comparative study on rendering of expressive meaning in two English versions of Hong Lou Meng by the Yang's and David Hawkes, aiming to find proper methods for the rendering of expressive meaning in "Jinling Prophecies" and the twelve songs, and to examine to what extent they can be translated and accessible to English readers.
Since the first appearance of this great Chinese classical works, numerous studies have been done on it, concerning almost every aspect of the novel, but there are few studies no matter on interpretation about expressive meaning in "Jinling Prophecies" and the twelve songs or on translations of the two as a whole. And here would be the first time the concealing psychoinformation of Cao Xueqin and the main characters are analyzed as a research object on expressive meaning in translation studies. Research questions of the paper are as follows: To what extent expressive meaning in "Jinling Prophecies" and the twelve songs can be rendered in target language? How has it been rendered in the two English versions? How much has been rendered? Are the renderings appropriate or not? What criteria can we follow in translating the two pieces?

\section{An Overview of Expressive Meaning}

\section{Expressive meaning in previous studies}

In terms of expressive meaning, we shall firstly introduce the term "meaning" - a central topic in human scholarship. Geoffrey Leech recognizes seven types of meaning in his Semantics: The Study of Meaning (1974: 23) which are as follows: conceptual meaning, connotative meaning, social meaning, affective meaning, 
reflected meaning, collocative meaning, and thematic meaning. Besides, connotative meaning, social meaning, affective meaning, reflected meaning and collocative meaning are summed up into "associative meaning". So Leech's model can also be briefly listed as conceptual meaning, associative meaning, and thematic meaning. Affective meaning here is "what is communicated of the feelings and attitudes of the speaker/writer". Yet by D. A. Cruse (1986), this type of meaning is termed "expressive meaning" and associative meaning is "evoked meaning".

When analyzing the components of lexical meaning of Cruse's model, it shall start out by introducing Mona Baker's theories about nonequivalence at word level. Mona Baker (1992) in her book In other words: a coursework on translation summarizes four main types of meaning in words and utterances that derived from Cruse: propositional meaning, expressive meaning, presupposed meaning and evoked meaning. Based on the theories of Cruse, Baker contends that the "propositional meaning of a word or an utterance arises from the relation between it and what it refers to or describes in a real or imaginary world, as conceived by the speakers of the particular language to which the word or utterance belongs. It is this type of meaning which provides the basis on which we can judge an utterance as true or false. ...Expressive meaning cannot be judged as true or false. This is because expressive meaning relates to the speaker's feelings or attitude rather than to what words and utterances refer to. ...Presupposed meaning arises from co-occurrence restrictions, i.e. restrictions on what other words or expressions we expect to see before or after a particular lexical unit. ...Evoked meaning arises from dialect and register variation. A dialect is a variety of language which has currency within a specific community or group of speakers. ... Register is a variety of language that a language user considers appropriate to a specific situation. ...Different groups within each culture have different expectations about what kind of language is appropriate to particular situations" (13-16).

This paper intends to follow Cruse's model on the components of lexical meaning and focuses on expressive meaning in translation studies. As for Cruse's model on the components of lexical meaning, the most close-related meanings to expressive meaning are propositional meaning and evoked meaning according to the relationship among the four types. Thus Chen Xin (2007: 52) further divided expressive meaning into two types: one is direct expressive meaning which can be understood by the favor of propositional meaning; the other is indirect expressive meaning which can not be simply understood through propositional meaning but evoked meaning. Due to the inevitable differences in evoked meaning of the same thing in different circumstances, the indirect expressive meaning can also be divided into two types: one is having related equivalent word in target language when evoked meanings of the same thing are different; the other is no related equivalent word in the same situation. However, another problem arises from here: even the equivalent word exist in two cultures or circumstances, upon which groups from the two sides not necessarily feel the same way as each other does. When it is rendered in its original form, the logical content as well as certain encyclopedic assumptions of the expression may get lost as a result.

\section{Expressive meaning in this study}

The concealed expressive meaning in Hong Lou Meng is indirect expressive meaning by definition as we have enumerated in the literature review. In this study, we will only focus on five beauties (with whom Jia Baoyu has subtle relationships) and their related poems in the main register of "Jinling Prophecies" and the twelve songs. The original poems are relisted as follows:

(1)[红楼梦引子] 开辟鸿蒙，谁为情种？都只为风月 情浓。趁着这奈何天, 伤怀日, 寂寥时, 试遣愚 衷。因此上, 演出这怀金悼玉的《红楼梦》。

(Cao, 2008: 82)

(2) 可叹停机德, 堪怜咏絮才。

玉带林中挂，金穊雪里埋。(Cao, 2008: 76)

(3) [终身误] 都道是金玉良姻, 俺只念木石前盟。 空对着, 山中高士晶莹雪; 终不忘, 世外仙姝寂寞 林。叹人间, 美中不足今方信。纵然是齐眉举案, 到底意难平。(Cao, 2008: 82)

(4) [枉凝眉]一个是阆苑仙菂, 一个是美玉无瑕。若 说没奇缘, 今生偏又遇着他; 若说有奇缘, 如何心 事终虚化? 一个枉自嗟呀, 一个空劳牵挂。一个是 水中月, 一个是镜中花。想眼中能有多少泪珠儿, 怎经得秋流到冬尽, 春流到夏! (Cao, 2008: 82)

(5) 富贵又何为, 襁褓之间父母违。

展眼吊斜晖，湘江水逝楚云飞。(Cao, 2008: 77)

(6) [乐中悲] 襁褓中, 父母叹双亡。纵居那绮罗从, 谁知娇养? 幸生来, 英豪阔大宽宏量, 从未将儿女 私情略苶心上。好一似, 雯月光风耀玉堂。斯配得 才貌仙郎, 博得个地久天长, 准折得幼年时坎坷形 状。终久是云散高唐, 水涸湘江。这是尘寰中消长 数应当, 何必枉悲伤! (Cao, 2008: 83)

(7) 欲洁何曾洁，云空未必空。

可怜金玉质，终陷淖泥中。(Cao,2008: 77)

(8) [世难容]气质美如兰, 才华卓比仙。天生成孤癖 人皆罕。你道是啖肉食腥膻, 视绮罗俗厌; 却不知 太高人愈妒, 过洁世同嫌。可叹这, 青灯古殿人将 老; 古负了, 红粉朱楼春色阑。到头来, 依旧是风 尘肮脏违心愿。好一似, 无瑕白玉遭泥陷; 又何

须，王孙公子叹无缘。(Cao, 2008: 83) 
(9) 情天情海幻情深, 情既相逢必主淫。 漫言不肖皆荣出, 造畔开端实在宁。(Cao, 2008: 79) (10) [好事终] 画梁春尽落香尘。擅风情, 秉月貌, 便是败家的根本。箕雯颓邽皆从敬, 家事消亡首罪 宁。宿蒘总因情。(Cao, 2008: 86)

(11) [收尾·飞鸟各投林] 为官的, 家业调零; 富贵 的，金银散尽; 有恩的，死里逃生; 无情的，分明 报应。欠命的, 命已还; 欠泪的, 泪已尽。冤冤相 报实非轻, 分离聚合皆前定。欲知命短问前生, 老 来富贵也真侥幸。看破的，遁入空门; 痴迷的，枉 送了性命。好一似食尽鸟投林, 落了片白茫茫大地 真干净! (Cao, 2008: 86)

\section{A Comparative Study on Rendering of Expressive Meaning in the Main Register of "Jinling Prophecies" and the Twelve Songs}

\section{Analysis on expressive meaning in the original poems}

Hong Lou Meng (A Dream of Red Mansions/ The Story of the Stone) can be seen as a dream dreamt and acted by Jia Baoyu (the protagonist) or a tragedy written and directed by Cao Xueqin (the author). It is a tragedy about women, not a woman, but the women of the feudal society where Cao Xueqin was in. The superb point of this masterpiece is that what Cao Xueqin had witnessed and experienced at that time in the realistic world was artistically revealed through Jia Baoyu's eyes in the aesthetic world. That is to say, the complexities of the relationship among the author, the protagonist and the works itself are beyond readers' imagination. Let's try it in this way: Cao Xueqin is actually the real dreamer of the dream based on his golden days, and Jia Baoyu plays protagonist in Cao Xueqin's dream which was written and directed by the dreamer himself. And who is the narrator or who are the narrators of this story is still open to dispute. So the situation is even worse, we shall only leave it to the redologists and just explore expressive meaning as the research object, which "relates to the speaker's feelings or attitude rather than to what words and utterances refer to". Nevertheless, one thing we can confirm is that "the speaker" in the quotation means "two speakers" in the research text and even more: one is Cao Xueqin (or the fairy Disenchantment) and the other is Jia Baoyu. Why "or the fairy Disenchantment"? We will explain it in the following passage. For this reason, the concealing psycho-information for both of them (the author and the protagonist) shall be taken into consideration as a crucial element to decode and analyze expressive meaning in the original poems in Chapter 5 .

As for Chapter 5, it is considered to be the leading chapter of the whole works. In this chapter, Baoyu sank into a confused sleep in Qin Keqing's bed and came into the Land of Illusion where the fairy Disenchantment, whose business is with love-debts of human world, disenchanted him with registers of "Jinling Prophecies" at the first place and then the twelve songs, to awake him the Buddhist understanding that earthly existence is an illusion and karma determines the shape of our lives. That is why "Jinling Prophecies" and the twelve songs should be studied as a whole. Besides, the reason why Cao Xueqin and the fairy Disenchanted is overlapping is because the author sometimes expresses himself on certain characters by the mouth of the Disenchanted, yet not all the philosophies in "Jinling Prophecies" and the twelve songs are the author's idea but for catering to the position of the character. However, after the overall disenchantment Baoyu still didn't understand the preaching riddles though his meeting with the fairy Disenchantment was by no accident. We shall decode their expressive meaning from the prelude.

\section{On the Prelude}

In [红楼梦引子](the prelude), the first sentence “开辟 鸿蒙, 谁为情种” is a rhetorical question made by Disenchanted the composer, asking if there is any one who is unswervingly faithful to love since Pangu has split heaven and earth apart from the chaos (refers to China's creation myth). The answer or the answer-like sentence is “都只为风月情浓”, and “都” here suggests “all” or “without exception”. “风月” is an euphemism refers to sexual intimacy or sexual affair between man and woman. Here, we need to reaffirm that the fairy Disenchanted is in charge of love-debts, to compose and to perform the twelve songs is her way to disenchant girlish heartbreaks and male philanderings in human world. So the first two sentences convey her disdain on mortal's love that is no one in human's world is always passionate to love but sexual intimacy and there is no exception; or we may infer from another perspective that she carries the tone of a pessimistic mortal to express her disappointment and helplessness for true love. Therefore, the prelude indicates why and what to put on in Hong Lou Meng - all about love.

\section{On Lin Daiyu and Xue Baochai}

Lin Daiyu and Xue Baochai share one prophecy and one song in Chapter 5 but there is a separate piece specifically for Daiyu. The phrase “可叹” in the shared prophecy suggests that the author feels sorry for Baochai's no-return wifely virtue and “堪怜” expresses strong sympathy for Daiyu's disapproved talents. In feudal society, one of the traditional moral standards for women is “女子无才便是德”, which means women do 
not need to be talented but to unquestionably obey their husbands. So Daiyu's superb talents couldn't be recognized at that time while Baochai's female virtues were commonly approved in the Jia family except Jia Baoyu though. Just as the last two sentences of the prophecy predict that both of them are the slaughtered lambs of the arranged marriage system in feudal society - one is the jade belt hanging in the wood that is ignored by the world; and the other is the gold pin buried beneath the snow that is left out in the cold.

[终身误] is the shared piece for Baochai and Daiyu, which carries Baoyu's tone to complain dissatisfaction on his arranged marriage. “金玉良姻” in first sentence just refer to this loveless marriage between Baoyu and Baochai but thought highly of by the Jia family. “良姻” means “perfect marriage”, and “都” here also means "all” or "without exception". So every member of the elder generation believes that the Gold and the Jade are well-matched and the marriage must have a good prospect. However, Baoyu himself doesn't think so. “木石前盟” refers to the engagement between Baoyu and Daiyu in their previous life. “念” here means "to think of" or "keep thinking about", and “只” emphasizes “only" or "just". No matter how perfect the marriage could be, only the engagement with Daiyu will always keep in mind for Baoyu. This state of mind can also be inferred from the following phrases: “空对着” which refers to Baoyu's feeling about Baochai, and “终不忘” about Daiyu. The original meaning of “空” is "empty". It is an adverb here to describe a hollow state of mind that related to "absentminded". Although Baoyu and Baochai were united in marriage as the whole family wishes, Baoyu always keeps thinking about his soul mate Daiyu. Thus in the name of Disenchanted the author sighs with regret that it can't be perfect always in human world and it is hard to satisfy both sides (“叹人间, 美中不足今方信”). Even the wife is courteous and kind, with whom Baoyu lacks an emotional connection. He can't mask his feelings after all, which is what conveys from “意难平”.

[枉凝眉] is just like a love song to Daiyu in Baoyu's inner part yet from the third party's point of view, which expresses his great affection for her, helpless condemnation of the arrangement, and deep concern about her sickness. As the story goes from the beginning, Daiyu is the reincarnation of a flower from paradise (“阆苑仙葪”), and to repay Divine Attendantin-Waiting with tears for watering her in the previous life, which is the purpose of her mortal birth. Baoyu is just the incarnation of Divine Attendant-in-Waiting who is born with a piece of flawless jade (“美玉无瑕”). Judging from this, their earthly meeting should be a destined romance and the character “偏” can fully express the speaker's feeling on this expected destiny, yet finally there is no happy ending and they two just rejoiced too soon (“终虚化”). “枉” and “空” both convey their state of frustration and disappointment and tell the fact that their hopes come to nothing and what they have tried is just in vain.

\section{On Shi Xiangyun}

The prophecy for Shi Xiangyun is a summary of the song [乐中悲] - one summarizes the other, and the other describes the one in details with explanation.

Although the first half sentence of the prophecy is an interrogative sentence, it dose not expect an answer but present the answer afterwards: even if Xiangyun was born with a silver spoon, so what does it matter (“富 贵又何为”) ? Indeed, it doesn't. “袺褓” in second half means "swaddling clothes" that is a metaphor used to signify "infancy"; and according to Lun Heng (《论 衡·知实》) written in Han Dynasty, “违” here means “to leave behind” which refers to her parents" death (“双 亡” in the song). Orphaned since her infancy, Xiangyun grows up under the watchful eyes of her wealthy maternal aunt and uncle who treat her unkindly. She can not feel any warmth in her growth stage but solitude as what the first two sentences indicate in the song, and the character “叹” which means “sigh" that we may infer author's sadness on Xiangyun's misfortune. Despite this, the big-hearted tomboyish girl is always cheerful and never indulge herself in love as Daiyu does, which is gratified the author from the character “幸” ("fortunately" or "happily"). It is thus clear that how much Cao Xueqin likes the figure Xiangyun, and from whom he wants to tell the readers that misfortunes can be turned into fortunes with optimism. From the inner part, Cao Xueqin wishes a promising future for Xiangyun to redeem what she has suffered before, a well-matched Mr. Perfect or a long-last marriage, for instance. Nevertheless, there is no happy ending in this dooming tragedy for women. As for Xiangyun, no happiness at last but loneliness again in the twinkling of an eye (“展眼吊斜晖”) and what more tragic is that the tragic heroine is a cheerful one. Why tragedy always? We may infer from the last sentence of the story that everything in human's world is always ordered (“尘睘中消长数应当”) and of no avail to be sad (“何必枉悲伤”). Though with dissatisfaction and distress, the author is inevitably fettered by fatalism and put all the blame on the fate per se, or we can say that fate is the only rational explanation he could find to explain such an irrational world.

\section{On Miaoyu}

Miaoyu is a beautiful and learned but aloof nun from 
Buddhist cloister of the Rongguo House, compelled to become a nun by her mundanely incurable disease, and being extremely fastidious about cleanliness. In her prophecy, “欲” in first sentence means "to want" or "to wish" and “云” means "to say"; the phrase “何曾” is used in rhetorical questions that means "never (did)", and “未必” means "may not” which expresses a sort of doubt about what it looks like. The original meaning of “洁” is "cleanness", but here refers to its extended meaning that is "virginity" or refers to one of the Buddhist disciplines according to different interpretations; and “空” ("nothingness" or "illusion”) is related to the Buddhist understanding: everything in earth is illusory and will be melted into nothingness eventually, which is “虚无就是一切, 一切都是虚无” (Liu, 1990: 66). The first half sentence prophesies Miaoy's final fate that she is abused by an old man in the end according to Rouge Inkstone's commentaries, as the last half of the prophecy goes “终陷泥淖中” ("ends up in the mud"). Alas, this tragic result is extremely cruel to such pure, proud and aloof girl compared with other girls” tragedies. As for “云空未必 空”, compelled to become a nun Miaoyu might not say good-bye to the dusty human world especially to the sense of love (the hidden affection for Baoyu). So the state of “空” may have little to do with Miaoyu although it seems to be.

In the song of [世难容], Miaoyu's appearance and talents are highly approved by the author but her aloofness while her extreme cleanliness is disapproved by others. As a result, she is envied for her superiority and set herself “with the rest at odds” (“世同嫌”). Her final fate is just like a white and flawless jade dropped in the mud (“好一似, 无瑕白玉遭泥陷”), which Baoyu would sigh in vain for getting no chance to be with (“又 何须, 王孙公子叹无缘”), although Miaoyu's final fate remains open to speculation.

\section{On Qin Keqing}

Of all the characters in the novel, Qin Keqing is one of the most mysterious but significant ones. According to the novel, the life and early death (related to an affair with her father-in-law) of this glamorous and flirtatious woman, who is considered as Two-In-One (Xue Baochai and Lin Daiyu), is closely related to the changing fortunes of the Jia family. Her death has remained a mystery as well as the meaning of her name Qin Keqing (“秦可卿”). There is no need to go into details, but one thing we shall confirm is that the character “秦” (the family name of Qin Keqing) has similar pronunciation with “情” (“love”) in Chinese. There are four “情” in the first sentence of Qin Keqing's prophecy. Due to varieties of love, “情” here specifically refers to "amour" rather than "love"; and “秦” that refers to Qin Keqing is the incarnation of “情” whose "love" is quite different from those of common people. Apparently, the author criticizes this sort of love, from which lust (“淫”) comes out as the second half goes : “情既相逢必主淫”. The last sentence points out that descendents from the Duke of Ningguo must take the blame on the beginning for changing fortunes of the Jia family.

[好事终] (good things come to an end, “终” means "ending") is the last piece of the twelve songs. As much as we have summarized, there are three interpretations on the title which are as follows: the end of the secret love affairs (refers to the early death of Qin Keqing), the end of the Jia family (the changing fortune of the Jia family), and the end of the twelve songs. The first sentence indicates the fact that Qin Keqing commits suicide by hanging herself. The character “擅” and “秉” in ancient Chinese get similar meaning that is “arrogate” or “control”. “风情” and “月貌” are still related to “风月” (“sexual intimacy”), the previous one refers to "amour" and the latter means "amorous looks". “败家的根本” ("the root of the ruin") is related to the changing fortunes of the Jia family. Now, we may judge the whole sentence from this way: “风情” is the effect of “月貌”, and “风情月貌” causes “败家”, which signifies that the narrator put all the blame on Qin Keqing for the fall of the Jia family. In the third sentence, “敬” refers to Jia Jing who is the father of Qin's father-in-law, and “宁” refers to Ningguo house. This sentence aims to blame Jia Jing's ignorance and permissiveness on Qin's issue, which start Ning's scandals and firstly speed up the fall of the whole family. All in all, however, lust is always the root of the ruin and is already doomed in one's previous life, which what “宿蒘总因情” conveys. Again, fatalism explains all. Besides, another interpretation on the last sentence transforms “情” to “秦”.

\section{On the Epilogue}

[收尾·飞鸟各投林] is the epilogue of the twelve songs in Hong Lou Meng to sum up the final fate of the twelve beauties in Jingling and prophesizes the ending of the whole story, as the last sentence goes “好一似食尽鸟 投林，落了片白茫茫大地真干净！” (“When the food is gone the birds return to the wood; all that's left is emptiness and a great void").

It seems that “空” (“emptiness" or "nothingness") is the key word Cao Xueqin would like to express in whole works. Hong Lou Meng is not just another old story about the wit and the beauty, but from which the author pours out his heart on this terribly damaged society during its last years of feudalism while under the 
cover of the professed theme “大旨谈情” (all about love), which is a mixture of feelings he can not tell in an explicit way. That is what “愚衷” (“one's foolish heart") exactly refers to in the prelude of the twelve songs. On one hand, Cao Xueqin would like to reverse the falling situation of the feudal society; on the other hand, he doesn't know how, even he knows it is just out of his reach. Thus he is standing at the crossroads and sighing:

Found unfit to repair the azure sky

Long years a foolish mortal man was I. (Hawkes, 1973:49)

\section{Analysis on rendering of expressive meaning in the two versions}

Due to the cultural and linguistic differences between Chinese and English, limitations appear in the translation of Hong Lou Meng. In the 1970s, facing the great challenge, the British sinologist David Hawkes and the Chinese scholar Yang Xianyi and his wife

In this part, we will further Gladys Yang presented two complete versions with their great determination and passion, and therefore are frequently studied. David Hawkes entitled his version The Story of the Stone. He completed the translation version of the first eighty chapters in three volumes and subtitled respectively: "The Golden Days", "The Crab-Flower Club" and "The Warning Voice". John Minford, son-in-law of Hawkes, continued the translation of the last forty chapters. The Yang's A Dream of Red Mansions "together with David Hawkes' The Story of the Stone is taken as the two most authoritative translation classics of Hong Lou Meng in the Chinese translation field" (Lin, 1997: 282).analyze rendering of the expressive meaning in the main register of "Jinling Prophecies" and the twelve songs in the two versions, and have a comparative study on the lexical selection in target language for the two translators from three perspectives: culture, language, and psychology. The eleven poems will be analyzed in sequence.

\section{At Culture Level}

On the translation of the title for Poem (1), Yang's version is "PROLOGUE TO THE DREAM OF RED MENSIONS" and Hawkes" is "A Dream of Golden Days". Because of differences in aesthetic standards and thinking modes between Chinese and westerners, the color of red is favored by Chinese nation tracing back to the primitive sun worship and fire worship; yet may arouse negative evoked meaning about blood, violence or danger for the target readers in western civilization where the spirit of pragmatism to objective world and reality is advocated. Thus the readers will not relate the color of red to the springtime of boys and girls in Grand View Garden. Yet "Golden Days" may remind the readers "Golden Age", which comes from Greek mythology and refers to the first in a sequence of ages for man followed by the Silver, Bronze, and Iron Ages, and then the present, a period of decline. Each succeeding age was worse than the one that went before. In this way, Golden Age is the best time for mankind, and then Golden Days refers to the best days as it ought to be. Consequently, "Golden Days" realizes functional equivalence with the theme, and is much closer to the target readers' psychological expectations. As for “风 月" in second sentence, its original meaning in Chinese is "the wind and moonlight" that is an general reference to beautiful sceneries yet extended to be an euphemism refers to sexual intimacy or sexual affair between man and woman. Although we can find equivalent words from target language, it shall not be translated literally as "breeze and moonlight" or "the wind and moonlight" that may conveys positive effect rather than negative.

In Poem (2), “停机德” is a Chinese allusion from Book of the Later Han (《后汉书·列女传.乐羊子 妻》). The story goes like this: a man named Yueyang left home to pursue great learning. He returned home without any achievement a year later because of homesickness. On seeing him home, his wife cut off the cloth she had just waved on the loom to illustrate the fact that nothing could be achieved with half things done. From then on, the wife of Yueyang became a model on wifely virtue and “停机德” is the name of such virtue. There is no related equivalent word of “停 机德” in English, Yang and Hawkes respectively translate it as "wifely virtue" and "female virtue". Both of the two translations have rendered surface meaning of the virtue yet the deep meaning of the allusion gets lost as a result. Yang's translation seems more precise in range but if with a note briefly upon the allusion would be better. The note can be like this: the wifely virtue (pronounced as tíng jī dé in Chinese, which refers to an allusion that a wife cut off the cloth she had waved on the loom to illustrate the fact that nothing could be achieved with half things done as a warning for her husband who had quit the learning halfway.)

\section{At Language Level}

Yang translates the title of Poem (1) as "FIRST SONG" with a subtitle "PROLOGUE TO THE DREAM OF RED MENSIONS". The number of the twelve songs turns out to be 13 rather than the original 12 if arranged in this way. Hawkes respectively entitles the beginning and ending "Prelude" and "Epilogue", and songs between which are just ordered from "First" to "Twelfth". Judging from this, Hawkes' translation of the sequence is reasonable.

On the translation of “金䙃” in “金䙃雪里埋” of Poem (2), Yang's translation is "golden hairpin" while 
Hawkes' is "gold pin". "Golden" mostly emphasizes the color that is gold-like and "gold" emphasizes the quality itself. Apparently, Hawkes' "gold pin" is more favorable.

In processing “山中高士晶莹雪” and “世外仙姝 寂寞林” of Poem (3), Yang's translations are “the hermit in sparkling snow-clad hills" and "the fairy in lone woods beyond the world". We know that the characters “雪” and “林” respectively refer to Xue Baochai (the pronunciation for the character of her family name “薛” is the same as “雪” that means snow) and Lin Daiyu (“林” is just the character of her family name), but the term "hermit" is usually used to name a male who lives alone and has a simple way of life, which can hardly be related to the beauty Xue Baochai for English readers. Hawkes translates “山中高士晶芗 雪” as "crystalline snows of beauty pure and cold", avoiding the image of “山中高士” but keeping the image of “晶莹雪”. As “山中高士” and “晶莹雪” are in apposition as well as “世外仙姝” and “寂寞林”, Hawkes' translation has fully expressed what Cao Xueqin hided in the lines to achieve semantic identity between the key word “雪” and the family name “薛”, so his alternative decision on lexical selection can be seen as a nice attempt.

On the tense used in translation of the first sentence in Poem (4), Yang uses present tense that is "one is an immortal flower of fairyland, the other fair flawless jade", while Hawkes' translation is "one was a flower from paradise, one a pure jade without spot or stain", using past tense. According to the original novel, “阆苑 仙菂” and “美玉无瑕” are related to the previous life of Daiyu and Baoyu as we have mentioned in Chapter 3 that Daiyu is the reincarnation of a flower from paradise and to repay Divine Attendant-in-Waiting with tears for watering her in the previous life is the purpose of her mortal birth; Baoyu is just the incarnation of Divine Attendant-in-Waiting who is born with a piece of flawless jade. So it seems that past tense is more suitable to distinguish their mortal birth in the present from the incarnations in the past. As for “水中月” and “镜中花”, both of them are the images of illusion, which used to signify the fact that the insubstantial happiness of Daiyu and Baoyu would be doomed to pass. Yang translates “一个是水中月, 一个是镜中 花” literally as “one is the moon reflected in the water, the other but a flower in the mirror". The word "is" (“是” in Chinese) is often used to define things when something is exactly what it refers to, or used in a metaphor to signify the related things. Here, however, “水中月” and “镜中花” can not be the metaphors to signify Daiyu and Baoyu but what the two have experienced are as illusory as “水中月” and “镜中花”.
Hawkes's translation is more appropriate judging from this, which as follows: "All, insubstantial, doomed to pass, as moonlight mirrored in the water or flowers reflected in the glass". An "as" expresses all.

In Poem (8), Hawkes translates “仙” from “才华 阜比仙” as “the gods" that is a term used to name male beings in heaven. Thus being Miaoyu's prophecy, this selection is not appropriate. Yang's "immortal" is just open to dispute for such questions as what talents is an immortal possesses, how talented s/he is, and whether the talents can be compared with Miaoyu's are unable to measure. As for “天生成孤癖人皆罕”, Yang's translation is "yet so eccentric that all marvel at her". The word "eccentric" has negative effect that means behaving or appearing in a way that is unusual and different from most people, while the phrase "marvel at" is used to express one is feeling great surprise or admiration for someone's behavior and absolutely with positive effect. The two are conflicting with each other in meaning, so Hawkes' translation is more accurate to express the situation, which is "adding a strange, contrary nature that set you with the rest at odds".

The original meaning for character “春” of “画梁 春尽落香尘” in Poem (10) is “春天” or “春季” in Chinese that means "spring" in English. Yet the sentence prophesizes the fact that Qin Keqing commits suicide by hanging herself in such a young age, “春” here mostly refers to “青春” in Chinese that means "youth" in English (refers to a period of time when someone is young). Yang chooses "spring", but Hawkes uses "springtime"; and the latter is better to emphasize the "period of time". In terms of the key word “情” in “宿蕉总因情”, Yang's complete translation is “all their sins come about through love". Is love the root of sins? I dare not to agree as well as the target readers I believe. Lust, might be. Just as the traditional Chinese value goes “万恶淫为首” (Lust is the root of all evils). Hawkes transfers the concept of lust into "love's fashioning", indicating love is good but with too many people is another thing; and surprisingly it rhymes with the previous lines that rhymed/in/. It is really a successful attempt to transfer the concept lust or amour to love's fashioning.

Poem (11) is the epilogue of the twelve songs to sum up the final fate of the twelve beauties in Jingling and to prophesize the ending of the story or the society; it not only embodies the twelve female characters but all in the whole works even in the author's world according to his “愚衰”. Among them, “富贵的, 金银 散尽” mainly refers to Xue Baochai or her wealthy family but also includes other rich nobles in that era. “The rich man” (“富贵的”) in Hawkes” translation “the rich man's fortune now all vanished" seems limited in gender and in range as well. In this case, Yang's "rich 
nobles' wealth is spent" is more accurate. Similarly, the two translators" renderings of “看破的，遁入空门” are "those who see through the world escape from the world" and "the disillusioned to their convents fly", which mainly focuses on Jia Xichun. While according to the novel, Jia Baoyu also eventually becomes a monk. Hence the word "convent" which used to name a building or set of buildings where nuns live sees its limits in gender.

\section{At Psychology Level}

On the translation of “展眼吊斜晖” in Poem (5), Yang and Hawkes respectively translate it as "in a flash she mourns the setting sun" and "soon you must mourn your bright sun's early setting”. “展眼” is a overstatement to emphasize a really short time that as short as the twinkling of an eye, and “斜晖” (refers to sunset) in Chinese culture often symbolize that something is close to its end with emotions of regret, solitude, sadness, and unwillingness to part. “展眼吊斜晖” expresses the fact that no happiness at last for Xiangyun but loneliness again in such a short time, which the author feel sorry about. From this, "in a flash" is more favorable to emphasize "short" in an exaggerate way for it is much shorter than "soon". Hawkes uses "bright" to describe the sun Xiangyun mourns. It seems that "bright" is a bright word with cheerful effect that can not convey Cao Xueqin's sadness and regret on Xiangyun's misfortune, unless he uses a cheerful adjective to describe the cheerful girl as an irony or he would like to compare Xiangyun's previous happiness as a bright thing except the ending is coming too soon. It is still open to dispute.

Yang translates Miaoyu’s “欲洁何曾洁, 云空未 必空” in Poem (7) as “Chastity is her wish, seclusion her desire". As our analysis on this part, Miaoyu is actually compelled to become a nun by her mundanely incurable disease and might not say good-bye to the dusty human world. Her words and actions are often betrayed herself for the hidden affection for Baoyu. Judging from this, the decision to become a nun is not her orientation; there is just no alternative for her. Thus we can't judge that seclusion is her desire, all about the “空” (“emptiness" or "nothingness") for her may just be "vaunted" as Hawkes' translation: "for all your wouldbe spotless and vaunted otherworldliness, ...".

There exist significant differences between Yang and Hawkes in translations on “好一似，无瑕白玉遭 泥陷; 又何须，王孙公子叹无缘” in Poem (8). They respectively rendered it as "Even as flawless white jade dropped in the mud. In vain young scions of noble houses will sigh for her" and "Like a white, flawless jade dropped in the muck, where only wealthy rakes might bless their luck”. “王孙公子” here is mainly considered to refer to Jia Baoyu whom Miaoyu falls in love with secretly though she claims her as a “槛外人” (an outsider who refuses to accept any form of love in the world of mortals) in the novel, contrasting with Baoyu the “槛内人” (the insider). The “槛外人” and “槛内人” could have become a couple as the story goes yet Baoyu would sigh in vain for getting no chance to be with Miaoyu whose hope is betrayed at last. The differences on two translations mainly lie in the latter half. Firstly, on the translation of “王孙公子”, though both of them use plural form to present a general reference that means not only one “王孙公子” is related in this issue, Yang chooses "young scions of noble houses" without any emotions while Hawkes uses "wealthy rakes" with negative effect. Moreover, Yang renders “泥” as "mud" yet Hawkes as "muck" that embodies mud but refers more, which is something such as dirt, mud, or another sticky substance that makes something dirty. Why Hawkes renders “泥” in an abstract way ("muck") and uses such negative word ("rake”) to signify “王孙公子”? Is there any relationship between "muck" and "rake"? We may make a wild guess here. When "rake" used as a noun, it originally means a gardening/farming tool with a row of metal teeth at the end of a long handle used for loosening the soil or removing dead grass; it also used to name a man who behaves in an unacceptable way, having many sexual relationships and drinking too much (“浪子” in Chinese). While as a verb, "rake" is extended to mean to search a place very carefully for something. And "muckrake" specifically means to search for and expose real or alleged corruption, scandal, or likes, especially in politics. Thus we may infer that "rakes" in Hawkes' translation is a pun that both signifies the tools with metal teeth to search the muck for the drowning jade and the wealthy men who will save Miaoyu from torturing. Besides, Hawkes renders "only wealthy rakes might bless their luck", it conveys that only those wealthy rakes are the possible savers to rescue Miaoyu if they are lucky enough from his point of view. As for Yang's translation that "in vain young scions of noble houses will sigh for her", it seems rather close to the expressive meaning of original sentence “又何须, 王孙公子叹无缘”, leaving aside its plural form of “王孙公子”.

In Poem (9), Yang translates “淫” in the second half sentence as "lust", while Hawkes' translation is "wantonness" that is the noun form of "wanton", which is mostly used as "a wanton woman" who is considered immoral because she has sex with a lot of men. So the word "wantonness" has a tendency of describing women rather than men, and here mainly refers to Qin Keqing from Hawkes' side. However, the production of “情” depends on both sides (a woman and a man) not 
just a sin only related to the woman. There is a crucial element we shall clarify for objectively interpreting the figure of Qin Keqing in Hong Lou Meng is that what we have seen the Keqing is not the one in the original version where she is indeed described as "a wanton woman" who takes the major blame in the love affairs. However, an old man, officially called Ji Husou who is closely related to Cao Xueqin's family and whose identity is still a mystery, thinking of the family interests recommended him to leave the truth aside for the time being. So what we have read now on Qin Keqing is the deleted and rewritten version, in which he transfers the negative figure to an affirmative artistic image yet there still exist some negative marks as the prophecy goes, surprisingly gaining aesthetic values on this mysterious figure. Therefore, although Cao Xueqin (or the fairy Disenchanted) criticizes Qin Keqing seriously as "the root of the ruin" in [世难容], he would like to make the readers feel sympathy and regret for her, because she is arranged as the first sacrifice or victim of the feudal society in the whole works. It is clear that here should be a neutral word to refer to “淫”, and Yang's "lust" is an ideal choice to meet the author's orientation.

When translate “擅风情, 秉月貌, 便是败家的 根本” in Poem (10), Yang's version is "by nature passionate and fair as the moon, the true root is she of the family's destruction". As we have analyzed in Chapter 3, “风情” and “月貌” are still related to “风月” (“sexual intimacy"), the previous one refers to "amour" and the latter just means the "amorous looks" for this sort of appearance may arouse men's sexual desire. “败家的根 本" ("the root of the ruin") is related to the changing fortunes of the Jia family. “风情” is the effect of “月貌”, and “风情月貌” causes “败家”, which signifies that the narrator put all the blame on Qin Keqing for the fall of the Jia family. We can obviously infer that Cao Xueqin or the fairy Disenchanted says no to Qin Keqing's amorous appearance that leads to family disaster. From the author's side, Hawkes' translation is more successful that the lexical selection is exactly "amorous looks". Yang's “fair as the moon" is literally equivalent to “月貌”, but from which it can not arouse negative evoked meanings for target readers but positive instead.

In Poem (11), “无情的，分明报应” prophesizes Miaoyu's final fate. Hawkes may misunderstand the adjective “无情的” and translate it as "the cruel" that means "no humanity" or "without humanity". Indeed, “无情的” in surface can be rendered as "the cruel" in English if there is no certain context. Yet this “无情的” is totally different from that “无情的” in “无情的，分 明报应”. Miaoyu's “无情” refers to her refusal to accept any form of love in human world contrasted with the Buddhist world, or we can say "loveless". So “情” here refers to "love", “无情的” means "no love" or “without love" in Miaoyu's inner part. Hawkes misunderstands the meaning of the original sentence, but Yang renders it as "heartless" that gives no reason for criticism. The last sentence “好一似食尽鸟投林, 落了片白茫茫大 地真干净” is the theme of themes for the twelve songs even for the whole works. Yang renders that "when the food is gone the birds return to the wood; all that's left is emptiness and a great void" which emphasizes the objective fact that the reason why the birds return to the wood is because food is gone, so "food" is the point. While Hawkes' translation goes "like birds who, having fed, to the woods repair, they leave the landscape desolate and bare" that emphasizes the feeding action; the birds fly to all directions after having fed just like the ending of the story that without the protection of Jia's family or we can say after the changing fortune of $\mathrm{Jia}$, everyone is scattered to bless their own lucks when there is nothing left to take advantage from Jia. "Food" can be a metaphor of what they want and the one who feeds the birds is the Jia family or the power of Jia. Judging from this, Hawkes' translation expresses exactly what the author would like to express. However, another difference lies in the lexical selections on “落了 片白茫茫大地真干净”, one is “emptiness and a great void" and the other is "the landscape desolate and bare". As we have mentioned before, “空” (“emptiness" or "nothingness") is the key word Cao Xueqin is always indicating in Hong Lou Meng. If to meet with this theme, Yang's version is more apt to release the tragic emotions. Therefore, to combine the two translations with two tendencies above would be a better choice as a result.

\section{Conclusion}

By analyzing expressive meaning in the original poems and the two versions, we may draw a conclusion that regardless whether there exist an equivalent word, it can not be literally translated in its original form but had better with notes on the original expressive meaning in source text, in order to infinitely close to the aesthetic experience of source readers and to the psychological expectations of target readers. Besides, transformations on concept and image in translation sometimes contribute a lot to achieve the transformation of emotion no matter of the author or the works per se. Nevertheless, the most important criterion among all is the author's orientation in the whole works. To do an overall research on the background of the works is what a responsible and qualified translator should do before translating, including personal experience of the author, the whole work, all works of the author, even the literary fashion in that era the author belongs to.

By comparing the two versions, the author of the paper thinks that both of them having their strengths and 
weaknesses and we can hardly judge which is better. The Yang's mostly renders the text in the third person, which makes the language rather objective just as an omniscient narrator who is narrating the ins and outs. While Hawkes prefers to be in the first and the second person that may easily narrow the distance between the readers and the works, which makes the readers immerse themselves for real in the preaching by the fairy Disenchanted while reading. All in all, the language used in Yang's translation is not that authentic from the target language readers' side but almost completely maintains the expressive meaning for the works; Hawkes' translation is more accessible to the target language readers but the rendering of expressive meaning is limited sometimes, yet a rare masterpiece in translation of Hong Lou Meng in general.

The fundamental assignment of translation is to transform meaning in two languages. Yet meaning itself is complex and diverse, in which emotion is deeply embedded. Thus translators have to perceive the meanings of words and utterances very precisely in order to render them into another language appropriately. Consequently, to study expressive meaning in poetry translation will be of significance on rendering emotions in maximum and to make the target language readers obtain the same or at least similar aesthetic experience and pleasure as the source language readers get. The accomplishment of the author's effort might be trivial, yet the possibility of the promotion of communication and collision in this subject might not be neglected.

\section{References}

Baker, Mona. (2000). In Other Words: A Course book on Translation. Beijing: Foreign Language Teaching and Research Press.

Cao, Xueqin. (2008). Hong Lou Meng. Beijing: People's Literature Publishing House.

Chen, Xin. (2007). On Translatability of Expressive Meaning, Foreign Language Teaching and Research 38: 52-54.

Cruse, D. A. (1986). Lexical Semantics. Cambridge: Cambridge University Press.

Hawkes, David. (1973). The Story of the Stone. London: Penguin Group.

Leech, G. (1974/1981). Semantics: The Study of Meaning. Harmondsworth: Penguin.

Leech, Geoffrey. (1987). Semantics. Trans. Li Ruihua and Wang Tongfu. Shanghai: Shanghai Foreign Language Education Press.

Lin, Huangtian. (1997). A Companion for Chinese Translators. Wuhan: Hubei Education Press, 282.

Liu, Fuyuan. (2003). On Rendering of Emotional Information in Yang's Version of Hong Lou Meng, Foreign Language Research 1:108-111.

Liu, Hongbin. (1990). Six Pairs of Contradictions in Character Images for the Twelve Beauties in Hong Lou Meng, A Dream of the Red Mansions 4: 66.

Liu, Jibao \& Bu, Xifeng (eds.) (2008). Masters' Comments on Hong Lou Meng I . Beijing: Beijing Library Press.

Shi, Jiasheng. (2002). Rendering and Lost of Expressive Meaning, Foreign Language Research 2: 89-91.

Wang, Hongyin. (2001). 50 Poems in a Dream of Red Mansions A Comparative Study of Two English Versions. Xi'an: Shaanxi Normal University General Publishing House CO.,LTD.

Yang, Jinmei. (2001). Jinling Prophecies and Their Translation in the Two English Versions of Hong Lou Meng. A paper submitted in partial fulfillment of the Requirements for the degree of Master of Arts. Xi'an: Shaanxi Normal University

Yang, Xianyi. (1995). A Dream of Red Mansions. Beijing: Foreign Languages Press.

Zgusta, L. (1971). Manual of Lexicography. The Hague: Mouton. 